\title{
Alienation and fetishism in Karl Marx's critique of political economy
}

Alienação e fetichismo na crítica da economia política de Karl Marx

Tomás Lima Pimenta (1)

(1) New School for Social Research

\section{Abstract}

This paper explores the connection between the concepts of alienation and commodity fetishism in the work of Karl Marx and their role in his critique of political economy. It analyses the different types of alienation present in his early work, linking them to the issue of fetishism in his mature work, and shows how the notion of alienation is subsumed by his theory of fetishism. In its conclusion, the paper attempts to establish the fundamental characteristics of commodity fetishism and the manner in which this concept expresses a radical criticism of modernity. Finally, the paper demonstrates that the critique of modernity and its modes of socialization, as Marx understood it, required engagement with and criticism of political economists, given that the modern mechanisms of alienation and fetishism are fundamentally grounded upon economic practices.

\section{Keywords}

Karl Marx, Alienation, Fetishism, History of Economic Thought, Critical Theory.

JEL Codes B51, B14, B40.

\section{Resumo}

Esse artigo explora a conexão entre os conceitos de alienação e fetichismo da mercadoria na obra de Karl Marx e seu papel na crítica da economia política. $O$ artigo analisa os diferentes tipos de alienação presentes na obra de juventude de Marx, articulando-os com o tema do fetichismo em sua obra madura, mostrando como a noção de alienação é subsumida pela teoria do fetichismo. Para concluir, este artigo busca estabelecer as características fundamentais do fetichismo da mercadoria e a maneira pela qual esse conceito expressa uma crítica radical à modernidade. Finalmente, este artigo demonstra que a crítica à modernidade e seus modos de socialização, como Marx as entendia, demandava um engajamento e uma crítica dos economistas políticos, dado que os mecanismos modernos de alienação e fetichismo são fundamentalmente baseados em práticas econômicas.

\section{Palavras-chave}

Karl Marx, Alienação, Fetichismo, História do Pensamento Econômico, Teoria Crítica.

Códigos JEL B51, B14, B40. 


\section{Introduction}

In an enigmatic posthumously published manuscript Walter Benjamin writes that capitalism should be seen as a religion, in the sense that it "essentially serves to satisfy the same worries, anguish, and disquiet formerly answered by so-called religion" (BENJAMIN, 2005, p. 259). However, there is for him a fundamental difference between capitalism and conventional religion: capitalism does not possess any theology or dogma, but is instead the permanent celebration of a cult. In capitalism, the transcendence of God has collapsed, but God himself is not dead. Rather, he has been incorporated into human destiny.

Modernity is usually understood as the moment at which life became both more prosaic and profane, science and technology provided human beings with unprecedented dominance over nature, and theology was eliminated from the domain of knowledge. If this was indeed the case, how could Benjamin interpret capitalism - the mode of production inherent to modernity - as something essentially religious? One possible answer is that while the dissolution of feudal society permitted human beings to cast off their old chains, they produced, in embarking upon the path of the development of reason, new illusions and enchantments, submitting themselves to new forms of slavery, and, in doing so, defied the expectations of the Enlightenment. The reign of freedom and reason did not become manifest as expected and announced.

Some years later, Theodor Adorno and Max Horkheimer undertook an original critique of the paradoxical nature of modernity in the The Dialectic of Enlightenment, just as Benjamin had done previously. They argued that modern rationality exists within a dialectic between myth and enlightenment, manifest in history in the form of the antithesis between civilization and barbarism. In the preface to the work, published in 1944, the authors wondered, "why humanity, instead of entering a truly human state, is sinking into a new kind of barbarism?" (ADORNO \& HORKHEIMER, 2002, p. xiv; GS 3, p. 11)

The paradox between civilization and barbarism was of great concern to Karl Marx in his critical reflections. In the Communist Manifesto, economic crisis, more specifically, the crisis of overproduction is taken to be the model for this paradox: in such a crisis, barbarism is the result of the 
excess of civilization (MECW 6, pp. 489-90; MEW 4, p. 468) ${ }^{1}$. In his lifetime, Marx observed immense development of productive forces, the dissolution of the old nation states, and significant political upheavals in 1848 and 1871. At the same time, he witnessed the impoverishment and brutalization of large masses of workers, the emergence of squalid living and labor conditions, and more generally, a total contempt for human life. In one of the most celebrated passages of the Communist Manifesto, Marx and Engels write that "all that is solid melts into air, all that is holy is profaned, and man is at last compelled to face with sober senses, his real conditions of life, and his relations with his kind" (MECW 6, p. 487; MEW 4, p. 465). The dissolution of the old and traditional social relations, however, brought with it new forms of illusion and alienation. For Marx and Engels, bourgeois society, with its development of productive forces, and the subjugation of nature to industry, is like the "sorcerer, who is no longer able to control the powers of the nether world whom he has called up by his spells" (MECW 6, p. 489; MEW 4, p. 467). In capitalist modernity, something connected to human beings' very constitution, the product of their consciousness and labor, become removed from them, and they perceive it as something external and uncontrollable. Modernity, before it could fulfill the enlightened ideal of dominating nature and realizing freedom in a complete sense, produced its own negation.

The aim of this paper is to show how, for Marx, the critique of modernity and its modes of socialization depends entirely on the critique of modern political economy and its understanding of the modern modes of socialization. We will illustrate that the notions of alienation and fetishism perform a key role in linking the critique of political economy to a more general criticism of modern forms of life. Alienation assumes a significant role in the philosophy of the younger Marx, when his ideas are still heavily informed by the tradition of German idealism. In the first section, we will present four forms of alienation described by Marx in his early writings: religious, philosophical, political and economic. Fetishism, on the other hand, is more present in Marx's mature work, particularly in Capital, and will be analyzed in the final part of this pa-

1 For Karl Marx and Friedrich Engels' works I have consulted the German Dietz Verlag "Karl Marx und Friedrich Engels Werke 1-43" (MEW) and the English Lawrence \& Wishart "Marx \& Engels Collected Works 1-50" (MECW) as indicated in the References section. I indicate the edition followed by the volume number and page number. 
per. In addition to exploring and elucidating these concepts, this paper aims to answer the following question: to what extent is the concept of fetishism compatible with the concept of alienation? Is there a logical and linear development between the two concepts or is there an epistemological rupture between them?

\section{The theory of alienation: the young Marx between 1843 and 1844}

In the preface to A Contribution to the Critique of Political Economy of 1859, Marx briefly described his theoretical trajectory, mentioning the time in which he found himself "in the embarrassing position of having to discuss what is known as material interests" (MECW 29, pp. 261-2; MEW 13, p. 7) when editor of Rheinische Zeitung between 1842 and 1843. The "material interests" to which Marx refers are the law against stealing firewood and the issue of land distribution (MECW 1, pp. 224ff; MEW 1, pp. 109ff). To solve the questions that were bothering him, Marx undertook a "critical revision" of Hegel's Elements of the Philosophy of Right.

This period is of fundamental importance in understanding Marx's later thought, which cannot be effectively approached without an awareness of the European philosophical tradition. Marx's initial point of departure lies in the issues that had concerned his philosophical predecessors. The treatment of the concept of alienation in German idealism emerges from the diagnosis of the needs of post-revolutionary European humanity, confronted with the ideals of rationality and organicity, ideas that underpinned the Enlightenment [Aufklärung] and the expressionist impetus of Romanticism, respectively. The contradictory demands of the Enlightenment and of Romanticism led to two distinct ways of understanding the problem of alienation in $19^{\text {th }}$ century Germany. For some German intellectuals, it was expressed in the situation of the modern individual as the inhabitant of an atomized and fragmented urban bourgeois society, lost in private life and unable to belong to an organic ethical totality. For others, it emerged as an opposition between the essence of the human person as a free, rational and conscious being and the actual historical situation of humanity. For these thinkers, the distance between those poles measures the loss or alienation of the human essence (LIMA VAZ, 1987). 
Marx explores the theme of alienation in several key texts from 1843 and 1844. Even in his youth, Marx had already accomplished an important break with his German intellectual background. For him, Hegel's annulling of alienation is merely formal and abstract because alienation itself is not well understood, that is, for Hegel "all estrangement [alienation] of the human essence is therefore nothing but estrangement of self-consciousness" (MECW p. 334; MEW 40, p. 575). The problem is, in effect, to comprehend real alienation. For expository purposes, we distinguish Marx's conception of real alienation in four forms: religious, philosophical, political and economic alienation. In the following sections, we consider each of these four aspects.

\subsection{Critique of religious alienation}

Marx's critique of alienation as such, as seen in the state, speculative philosophy or labor, ultimately has its origin in his critique of religion. Ludwig Feuerbach (1804-1872) was a seminal on Marx in this regard, through his critique of religion and through his reading of Hegel. Marx even wrote in 1844 "for Germany, the criticism of religion has been essentially completed, and the criticism of religion is the prerequisite of all criticism." (MECW 3, p. 175; MEW 1, p. 378).

What is the essence of this critique of religion? Marx's main point is that human beings make religion; religion does not make human beings. Religion is the self-consciousness of humanity, not an abstract humanity, nor a humanity distant from the world, but human beings within a given set of social and material conditions. What interests Marx is the human; in other words, the social form into which human beings organize themselves to produce themselves and the sensible world. Religion, the inverted consciousness of the world, is merely the consciousness of an inverted world (MECW 5, p. 4; MEW 3, p. 534). In this sense, "the wretchedness of religion is at once an expression of and a protest against real wretchedness" (Ibid.).

Religion generates alienation in the sense that humanity creates an external God, which then comes to determine its relationship with the world. Marx argues that the more humanity puts into God, the less it retains in itself, as religion "is the fantastic realization of the human essence because the human essence has no true reality" (Ibid.). 
Shattering the illusion of religion therefore is the first step toward an effective critique of society. As Marx argues, "the criticism of religion is therefore in embryo the criticism of the vale of tears, the halo of which is religion" (MECW 3, p. 176; MEW 1, p. 379). Once religion has been overcome, it then becomes necessary to unmask the non-sacred forms of alienation: "the criticism of heaven turns into the criticism of the earth, the critique of religion into the criticism of law and the criticism of theology into the criticism of politics" (Ibid.). Exactly this will prove to be the philosophical trajectory of the young Marx, as we show in the following sections.

\subsection{Critique of idealism}

In his Critique of Hegel's Philosophy of Right, Marx undertakes both a critical analysis of the modern state and a critique of the German consciousness in politics and Recht. Marx's criticism of the modern state as such and his criticism of the Hegelian speculative interpretation of the state are interlinked, because Hegel's philosophy is the most universal expression, raised to the level of science, of the modern state. ${ }^{2}$

Marx's critique of Hegel's theory of law was highly influenced by Feuerbach's critique of Hegel. For Feuerbach, Hegelian philosophy remains within the domain of theology. To consider that the Idea posits reality, nature, the material world, is just "rational expression of the theological doctrine that nature, the material being, has been created by God, the nonmaterial; i.e., abstract, being." (FEUERBACH, 2012, p. 168). Marx adopted this insight of Feuerbach and thereby came to consider speculative philosophy as another form of alienation. Indeed, Marx argues that one of Feuerbach's greatest achievements was to prove that philosophy is "nothing else but religion rendered into thought and expounded by thought, i.e. another form and manner of existence of the estrangement of the essence of man" (MECW 3, p. 328; MEW 40, p. 619).

2 It is in our view simplistic to understand the relation between Hegel and Marx merely as a controversy between "Hegel's idealism" and "Marx's materialism". Some Hegel scholars argue that Feuerbach's and Marx's reading of Hegel is misleading. While evaluating such a claim would require an entirely separate paper it is remarkable that most of young Marx's puzzles, particularly those related to political economy, are already to be found in Hegel's writings and lectures. For a scholarly account of Hegel's reception of political economy see Chamley (1963; 1965), Waszek (1988) and Priddat (1990); for a relation between Hegel's rabble and Marx's proletariat see Ruda (2011). 
The notion that the Idea posits man and reality may only be conceived through the abstraction of man. This abstraction is operated by the modern state, as will be demonstrated. Against this form of alienation, Feuerbach suggests the "true" connection between thought and being, namely: "Being is the subject, thought the predicate. Thought comes from being, but being does not come from thought" (FEUERBACH, 2012, p. 168). This thesis is essential to Marx's critique of Hegel's Philosophy of Right. Feuerbach and Marx find that Hegel has inverted subjet and predicate, thought and being. Marx thus concludes that Hegel understands the family and civil society merely as logical moments of the idea of right. Thus understood, the subject is the Idea (the State), and the predicate is the concrete social relations between men (the family and civil society). In $\$ 262$ of the Philosophy of Right, Hegel describes the family and civil society (the social relations of market and the administration of justice) as "moments" of an immanent division of the "Idea" of right (HEGEL, 1991, p. 228). According to Marx, this paragraph holds the key to the mystery of Hegelian philosophy in general. How so? For Marx, the key problem lies in the fact that Hegel's division of the state into family and civil society is ideal, and therefore necessary, constituting the essence of the state. Consequently, family and civil society in Hegel are conceived of as moments of the concept of state, as finite parts of the concept of state. Marx then inverts these categories in a manner similar to Feuerbach, arguing that the state is issued from the social existence of the multitude, and not the other way around MECW 3, p. 9; MEW 1, p. 207).

For Marx, the state and its concept are a result of social practices that take place at the level of family and civil society, so that Hegel's claim that family and society are moments of the idea of the state is a mystification. This fundamental insight will remain with Marx throughout the rest of his intellectual trajectory. It is of great importance for the critique of political alienation, in the sense that the foundation of alienation must be sought within the very structure of civil society and the family. Ultimately, this will insight will lead Marx to see the nature of alienated labor and thus undertake the critique of political economy. Before considering those issues, we first analyze his critique of the modern state and its peculiar form of political alienation. 


\subsection{Critique of modern right}

In 1844, Marx published On the Jewish Question, a criticism of two articles written by Bruno Bauer on the possibility (or impossibility) of the emancipation of the Jews in Germany. Marx's main criticism of Bauer is that he grasps the problem only in its political dimension. Marx, in contrast, makes a distinction between political emancipation and human emancipation. This distinction hinges on Marx's critique of Hegel's idealist mystification. Political emancipation is understood as the political participation of human beings in the modern state qua citizens. Human emancipation, in contrast, is regarded as reconciliation at the level of social practices in the family and civil society. Hence, against Bruno Bauer, Marx wants to show the insufficiency of political emancipation.

Marx contends that political emancipation does not require the Jew to abandon Judaism; just as, in a general sense, it does not require human beings to abandon religion. Marx argues that political emancipation may coexist with religion, in the sense that the state can free itself from religion even while the overwhelming majority of the population remains religious. This is because political emancipation provokes a split in the individual between his material life - as a private individual of a family or as a person in civil society - and his political life - as a citizen belonging to the state.

Where the political state has attained its true development, human beings- not only in thought, in consciousness, but in actuality, in life - lead a twofold life. As a citizen of a modern state, the individual takes part into the life of a political community. There he is regarded as a communal being, member of the species. As a member of civil society, by contrast, individuals act according to their private interests, regard other individuals as a means, degrade themselves into a means, and become the plaything of alien powers (MECW 3, p. 153; MEW 1, p. 354).

Marx elevates life in the political community to the status of "heavenly" life, in contrast to the material life of bourgeois society, thus according politics a status similar to religion (MECW 3, p. 154; MEW 1, p. 355). Here the similarity between Marx's critique of the state and his critique of religion can be seen most clearly. The state is an abstraction that emerges from the insufficiency of bourgeois civil society. Human beings, as isolated individuals, see themselves as a generic being only through the prism of the state. But such a relationship puts him "in contradiction with himself" 
and this recognition of the human essence occurs only in "an abstract, narrow, and partial way" (MECW 3, p. 152; MEW 1, p. 353). Furthermore, Marx shows how the state's recognition of the "droit de l'homme", can in fact be reduced to recognition of the rights of the bourgeoisie. In other words, for the modern state, man is, in reality, the bourgeois, an isolated monad. In short, political alienation emerges because individuals are divided between their mundane, earthly, material existence, and their life in an abstract, generic and alienated sense.

\subsection{Economic alienation}

According to Theodor Adorno (GS 5, pp. 265ff), the notion of labor was essential to German Idealism's conception of thinking. Further, labor becomes the very model from which Hegel draws the structure of his notion of spirit: an ever originating and productive force, as becomes evident in his master-slave dialectic. Marx certainly draws his first insights on the notion of labor and activity (Tätigkeit) from this tradition. He then develops them further, first through a critique of alienated labor in bourgeois society, and then through an ontological critique of the Hegelian conception of labor and of classical political economy.

To claim with Marcuse (1998) that labor is an ontological concept is to argue that it apprehends the very being of human existence as such. On this account, in contrast to a naïve understanding of the concept, work should be understood as a fundamental event of human existence (Dasein), which permanently and continuously dominates the entire being of human beings. If this is the case, the alienation of labor may be seen as a fundamental ontological alienation, present in the concrete social relations of human beings.

In 1843, Marx began his studies of political economy, the domain in which the anatomy of bourgeois society should be sought (MARX, 1971). The first fruit of this effort was the work Kritik der Politik und Nationalökonomie (1844-46), which later became known as the Economic and Philosophic Manuscripts of 1844. It is here that Marx begins to consolidate his understanding of alienation, no longer in religious, philosophical or political terms, but defined according to economic categories. In the same way as he saw Hegel's speculative philosophy as a means to criticize the modern 
state, he found in political economy the means through which to criticize bourgeois society in its material relations.

From this moment on, Marx understood the fundamental ontological importance of the sphere of production. He came to recognize that human beings, as belonging to nature, must necessarily produce in order to maintain themselves and satisfy their basic needs. To achieve this, he must create a complex hierarchy of non-original needs. Consciousness and the psychic phenomena are grounded in this productive activity. Alienated consciousness, therefore, is the result of an alienated form of production. Even though the manuscripts of 1844 present important ruptures with Marx's Hegelian background, its grammar is still pervasive. As Ernest Mandel argues, these manuscripts represent a moment of transition in which "elements from the past are inevitably combined with elements belonging to the future", and this combination profoundly modifies both elements. We therefore do not see a new "system" or "ideology" but scattered fragments which contain many contradictions (MANDEL, 1971).

The analysis of alienation emerges from the critical approach political economy and its laws. Marx shows how the worker is downgraded from the condition of humanity to the condition of object or commodity, in the sense that labor power itself becomes a commodity. At the same time, the division of labor renders the worker increasingly dependent on limited, one-dimensional and mechanical forms of labor. The accumulation of capital makes the products of labor increasingly alien for the worker, just as the division of labor makes the worker increasingly one-dimensional and dependent. For Marx, the poverty of the worker is linked to movements of capital and competition between workers, and therefore, the precarious condition of the worker has a material basis, in the social division of production.

As such, a form of labor that presupposes private property and its laws is a form of alienated labor. For Marx, the process of production described by the political economy of the time necessarily implies an alienated concept of labor. As production increases, the worker becomes poorer; the more commodities are created, the cheaper is the value of the worker; finally, the greater the value of the world of things, the lesser the value of the world of men.

According to Marx, the alienated character of labor has three dimensions: the product of the labor, the act of production, and relation to spe- 
cies-being. The first refers to the fact that the labor's product confronts the worker as something alien, as a "power independent of the producer" (MECW 3, p. 272; MEW 40, pp. 511-2).

The alienation of the product of labor is generated by the worker apprehending it as something external, alien to him. The objective world that the worker creates becomes both removed from him and increasingly powerful, imposing laws upon him and ultimately coming to organize social life. For Marx, "the worker puts his life into the object; but now his life no longer belongs to him but to the object" (MECW 3, p. 272; MEW 40 , p. 512).

The second dimension to the alienation of labor is externalization in the act of production. The alienation of the product of labor is merely the result of alienation in the act of production. Labor is alienated in the sense that workers do not realize their potential; rather, they deny themselves. Rather than enlivening their physical and mental capacities, work deadens them. Labor is merely the means by which to satisfy necessities removed from labor. The alienation of the activity is the alienation of oneself, in the same way that the externalization of the product is the alienation of the thing.

The combination of these two forms of alienation - namely of the product of labor and from the act of production - leads to the third dimension of alienated labor: alienation of workers from their species-being, i.e. anthropological alienation. For Marx, humanity begets the objective world in a practical sense. In elaborating non-organic nature, human beings impose themselves as conscious, species beings. Alienated labor, in alienating human beings from nature and from themselves, in the sense that both the object and their own active function become external, implies the alienation of the individual human being from the human species. The life of the species becomes merely a means of individual life, and labor is performed only in order to satisfy needs. In this way, life appears as only the means of life.

In addition, Marx is also concerned with understanding this process from the perspective of private property; in other words, the relation of the non-worker to the worker and to the object of work. The bourgeois counterpart of the emergence of alienated labor for the wage-worker is the emergence of a political economy that now sees labor as the source of value. In a Hegelian move, Marx understands the science of political economy as a result of the movement of private property, which becomes 
for itself in consciousness. This science recognizes labor as its principle by incorporating private property into the human being; in other words, as private property becomes the essence of human beings, their labor become the only producer of wealth.

This transformation of labor into an ideology (ADORNO, GS 5, p. 270) is described by Marx as the overcoming of the système monétaire by physiocracy. Whereas the economists of the système monétaire recognized wealth only as something external to human beings, in the form of metal, physiocrats considered wealth to be the fruit of labor, if limited to agricultural labor. The development of industry subsequently lead classical economists to go beyond this restriction and consider labor as "the general nature of wealth and hence [...] the raising up of labor in its total absoluteness (i.e., its abstraction) as the principle" (MECW 3, p. 292; MEW 40, p. 546). Marx writes:

Because they make private property in its active form the subject, thus simultaneously turning man into the essence - and at the same time turning man as nonessentiality into the essence - the contradiction of reality corresponds completely to the contradictory being which they accept as their principle (MECW 3, p. 292; $M E W$ 40, p. 546)

The paradoxical cynicism of political economy lies in the fact that the worse the material conditions of work became, and the more alienated labor became, the more labor came to be apprehended in its universality as a principle. Paradoxically, the more private property developed, the more economists came to regard labor in its universality as the absolute source of wealth.

\section{From the theory of alienation to the theory of com- modity fetishism?}

The term fetishism was firstly used in 1756 by Charles de Brosses in his Du culte des dieux fétiches. Its first use was an attempt to outline the exact limits between the modern rationality and the so-called "primitive" thinking. The latter, according to De Brosses, was immersed in the enchantment and the cult of fetish gods (BASS, 2015; SAFATLE, 2010).

The word fetishism came from the old Portuguese word fetisso, which means "spell" and was used by colonizers of America to describe different practices of worshipping inanimate objects or the deification of animals or 
natural phenomena (ALAIN, 2012). The use of fetishism to characterize "primitive" thought became very popular between the $18^{\text {th }}$ and $19^{\text {th }}$ centuries and was employed by philosophers, such as Kant and Hegel.

From the European perspective, the cult of such objects represented the ground zero of representation. In opposition to Christianity, whose objects were taken to be representations, symbols and allegories, the objects of worship of indigenous populations were regarded by Europeans as "contingent" and "arbitrary". It was as if the magical properties of the thing were properties of the immediate objects themselves. The distinction between so-called primitive thought and modern rationality was understood to consist in the use of abstraction and representation. Abstraction means the capacity to move from the first sensible and immediate determinations of a thing to concepts and generic symbols. Hence fetishism was seen as the first religion, completely attached to immediate objects (SAFATLE, 2010).

Consequently, when Marx appropriated the concept of fetishism, this concept already had a pronounced history in the social thought ${ }^{3}$. Marx's great turn was to use the concept of fetishism as a predicate of modern society as such, identifying "primitive" traces inside the capitalist mode of production. Marx showed how the alienation which the "West identified in its Other, operates, in reality, within our disenchanted societies and at the core of our forms of life" (SAFATLE, 2010, p. 26). The critique of fetishism is therefore an important tool for the critique of modernity and its processes of socialization. In The Dialectic of Enlightenment Adorno and Horkheimer write that in spite of its aim to rid the world of magic, dissolve myths and annul imagination, Enlightenment had exactly the opposite effect. There is nothing more mistaken than to identify modernity with a linear increase in rationality. To the contrary, Enlightenment "regresses to the mythology it has never been able to escape" (ADORNO \& HORKHEIMER, 2002, p. 20; GS 3, p. 44).

In his famous essays on Marx's theory of value, Isaak Rubin established a relation between the theory of alienation and the theory of commodity fetishism. His argument hinges on Marx's supersession of the opposition between "species-being" and alienated form, rooted in the Feuerbachian anthropology we discussed before. Overcoming the anthropological perspective allowed Marx to formulate a scientific and historical theory of 
alienation, i.e. commodity fetishism. Nonetheless, the two theories are similar in the sense that both reveal how products of human labor - whether manual or intellectual - come to exist as something alien (RUBIN, 1990).

One of the principal steps in overcoming Feuerbachian anthropology was the elaboration of the manuscripts known as The German Ideology, written in collaboration with Friedrich Engels. In his criticism of Feuerbach, Marx argues that the sensible world is the product of society, in the sense that human beings are not merely sensible objects, but also active subjects. In each historical period, men organize themselves in a certain way for the production and reproduction of life, transforming their relation to nature and to each other. Marx defines each of these phases as "mode of production" (though in 1845 this concept had yet to reach full maturity). Each mode of production, or industrial phase, implies a specific mode of cooperation or productive force, and the totality of the productive forces constitutes a given social state. In this sense, Marx establishes a link between history and the material world, given that the history of humanity may only be grasped in terms of its relation to different industrial phases (the relation of human beings with nature) and to exchange (the form of exchange between men). This reasoning led Marx to assert, in the sixth of his Theses on Feuerbach, that the essence of the human is not an abstraction inherent to each isolated individual, but the totality of social relations.

Reichelt (2013) highlights that Marx begins to avoid the lexicon of German idealism, thus terms like alienation, externalization and species-being tended to disappear from his work. This is no coincidence, it is rather the result of a new understanding of the relation between history and nature. Likewise, Zelený (1968) argues that Marx is no longer concerned with issues from traditional ontology, such as the relation between "substance" and subject, or "species-being", or "material in general". Rather, he displays a greater preoccupation with the practical conception of reality and of truth. Nonetheless, in scrutinizing Marx's mature works, like Grundrisse and Capital, one can find frequent passages in which he discusses the problem of alienation (Entfremdung) as well (MECW 28, p. 94; MEW 42, p. 89). Following Mandel's interpretation, the question of alienation remains present as a broader theme, embracing a wider field than that of commodity fetishism, although Marx reduced "human alienation in society based on commodity production essentially to the reification of human and social relations caused by commodity relation" (MANDEL, 1971, p. 184). Essential 
to this shift in the formulation of the problem of alienation, in Marx's decision to begin his Critique with the notion of "commodity" (PAULA, 2008).

The theory of commodity fetishism deals with similar aspects of capitalist societies and encompasses the problem of alienated labor. However, it cannot be understood as a mere continuation or development of the concept of alienation since to do so obscures differentia specifica that constitutes the peculiar form of the commodity analysis. Commodity does not merely describe an objective power alienated from men as religion or social relations, but also communicates a deep comprehension of the very nature of capitalist society in its purest form. We next turn to the conditions for Marx's formulation of the theory of fetishism, before considering the theory itself in the final section.

\subsection{The Marxian theory of fetishism}

In his first writings, Marx used the concept of fetishism to describe those earlier economists who presented wealth existing only as an object or a particular form. In the Manuscripts of 1844, Marx refers to physiocrats as fetishists because they reduced wealth to the particular form of agricultural labor. He later used the concept of fetishism to describe the difficulty of the economists faced in dealing with the question of money. This problem was clearly identified in his Comments on James Mill's "Éléments D'économie Politique" (1844) when Marx showed the inadequacy of the Ricardian school's treatment of the contradiction of money: money is a commodity like any other and its value is determined in the same way as that of any other commodity is, however, at the same time, the real value of any other commodity is its exchange-value that in the last instance exists in money. Thus, money is not merely a medium of exchange but rather the most desirable thing. While this money fetishism is extensively explored in the Grundrisse, it is only in Capital that Marx discovered a more systematic solution to the problem of money by formulating a deeper solution to the problem of fetishism.

In formulating his critique of political economy, Marx needed a new form of exposition which did not impair his content. In one of his last manuscripts about political economy, entitled Notes on Wagner's "Lehrbuch der politischen Ökonomie", Marx writes that: 
I do not proceed from "concepts," hence neither from the "concept of value," and am therefore in no way concerned to "divide" it [between use-value and exchange-value]. What I proceed from is the simplest social form in which the product of labor presents itself in contemporary society, and this is the "commodity". (MECW 29, p. 544)

Since Marx found the elementary form of wealth in contemporary societies in the commodity, its analysis becomes the point of departure of his critique. By commodity however, Marx does not mean a simple use-value valid, trans-historically, but the very specific form assumed by wealth within exchange societies. According to Marx, criticism should make explicit the social relations of production, as they not only precede theory, but also reveal the connection between the social relations of production and the categories of political economy (MECW 35, p. 86; MEW 23, p. 89). What are then, the objective conditions that give rise to commodity fetishism? For Marx, they can be found in the capitalist economy, based on independent producers of commodities, who are property owners. These individuals possess the instruments of production and the necessary raw materials, as well as the products of their business. They also act autonomously, in that they decide individually the type and the quantity of goods to be produced, with the sole objective of making a profit by selling them on the market. The social link between the different producers consists only in the exchange, on the market, of the goods produced, and the goods produced in this system are commodities. Rubin (1990) highlights the most important elements of this mode of production: a) the individual producers are formally independent; b) they are materially interrelated, through the division of labor, and; c) the direct link between individual producers occurs by means of exchange, which affects, indirectly, their productive activity. Social relations, therefore, occur through the relation between objects, and as they are developed in different forms, they come to organize the very relations between men: objects personify social relations, and they constitute the links between people. The relation mediated by the most simple and abstract thing is the relation between producers of commodities - this, therefore, must be the point of departure.

The odyssey of the commodity, throughout the three volumes of Capital, exposes, theoretically, the different forms of the commodity in its concrete reality. For example, the commodity also manifests itself as money, capital, rent, interest, etc. However, these categories emerge 
only as theoretical forms of knowledge, as they are preceded by their concrete emergence in the relations of production (RUBIN, 1990). The commodity is therefore the precise point of departure for understanding fetishism, the cult of things that is the kernel of Marx's critique of classical political economy in the society in which the capitalist mode of production prevails.

Initially, the commodity appears as merely a use-value, something trivial that satisfies human needs. However, when taken as a commodity, it becomes replete with "metaphysical subtleties and theological niceties" (MECW 35, p. 82; MEW 23, p. 85). This enigmatic character, as shown previously, lies in the very form of the commodity. That is, there is nothing in the thing itself that generates these properties, rather they emerge when that thing is posited in a certain social relation, which imposes a certain form upon that material use-value. According to Marx's analogy, the product of labor, i.e. the thing, reflects [zurückspielen] to human beings the character of their own labor in such a way that this character seems to emanate from the thing itself. Furthermore, the product reflects social relation of the producer to the total labor of society, so that the connection between the individual producer and social production seems to be established by the thing:

A commodity is therefore a mysterious thing, simply because in it the social character of men's labor appears to them as an objective character stamped upon the product of that labor; because the relation of the producers to the sum total of their own labor is presented to them as a social relation, existing not between themselves, but between the products of their labor. (MECW 35, pp. 82-3; MEW 23, p. 86)

When the exchange of products becomes the only form in which particular types of workers may act effectively as links of a total social product, the relation of the producers has become mediated by things. This leads Marx to assert that social relations between producers no longer resemble directly social relations between people, but rather "material [dinglich] relations between persons and social relations between things" (MECW 35, p. 84; MEW 23, p. 87).

The fetishized character of the commodity is what leads Marx to draw a parallel with religion, and it is here where the proximity of the theory of fetishism with the theory of alienation is most apparent. Humanity invents gods, which seem endowed with independent life, so much so that they establish relations with human beings as though they were ex- 
ternal entities. A similar process occurs with the products of human labor when they acquire commodity form. In a commodity society, the relation between men is mediated by things.

Commodity fetishism is rooted in the very nature of the work that produces commodities, specifically, in its dual character. In the capitalist mode of production, labor is divided into the concrete and the abstract. Concrete labor refers to its specific useful character, as with, for example, the tailor who produces clothes, or the blacksmith who makes tools. Each type of concrete work participates in the division of labor in its own way, and therefore needs to be socially useful in order to satisfy a given social need. The abstract character of labor emerges with the development of commodity form, as the products of labor must be equivalent to others. It is as if the concrete characteristics of labor were eliminated, with the work becoming the productive expense of the brain, muscles, nerves, hands, etc. The abstract character of labor is its universal dimension, which permits the quantitative equivalence of different use values.

However, this does not emerge in the process of exchange. The dual character of labor is found in production, as "their character as values has therefore to be taken into account, beforehand, during production" (Ibid.). This observation refutes the notion that fetishism is just a supplementary thesis, a subjective phenomenon which occurs in the minds of individuals in a process of exchange. The fact that the social character of the product appears in the process of exchange is due to the fact that, in the world of commodities, the social character of private labors only appears in the process of exchange.

Classical economists - especially Adam Smith and David Ricardo revealed the relationship between the value of a commodity and the amount of work employed in its production, but did not consider the dual character of labor, the form of value which converts the value of commodities into exchange value. Marx sees this omission as rooted in the fetishistic character of bourgeois political economy, which tends to naturalize historical social relations. The specificity of the form of value is therefore lost, alongside the specificity of the commodity-form, and, later stages, of money-form, capital-form, etc. In the next section, we will explore how Marx's concern with the form works within his critique of political economy. 


\subsection{Form and appearance}

Recent interpretations of Marx have emphasized the role of form in his critique of political economy. According to this perspective, the great originality of Marx's analysis of the commodity lies on the fact that it reveals the "secret" of the very form of commodity (KARATANI, 2005; POSTONE, 2003; ŽIŽEK, 2008). Marx's most significant contribution lies not in the discovery that the value of a commodity is the socially necessary abstract labor-time required for production, but in his discovery of why socially necessary labor-time comes to constitute value in a given historical moment.

We would like to argue that the problem of form, which is the core of Marx's fetishism theory, is central to his critique of political economy. We would like to explain Marx's critical enterprise in a two-fold way. The first moment of the critique we shall call the "Kantian" moment: this refers to Marx's "Copernican Turn" which consists in the abandonment of the questions about the in itself of things and the move towards the study of forms, i.e. of how things appear to us according to objective categories. The second moment we may call the "Kracauerian" moment: the decoding of this "transcendental" structure, that is, the demonstration that such mode of appearance is necessary only to this historically determined mode of production and, therefore, that it is historically variant.

The Kantian moment has been well elaborated by Kojin Karatani (2005). By the Copernican Turn we refer to the way Kant shifted the problem of epistemology from the object to the subject, that is, from the question of "what the object is?" to the question of "how the object appears to me?". The answer to this question entails a detailed analysis of the categories of the understanding and of how the subject imposes a certain form upon the given. Marx showed that the character of the commodity and its further determinations (exchange value, value etc.) can only be understood under the determination of a certain form. Marx's analysis of the money-form is illuminating. The question is: how does a commodity become money? The answer is: by being posited in the "general equivalent form". As Karatani (2005) argues, the equation "relative form of value = equivalent form", for example, 20 yards of linen = 1 coat, means that the coat only seems to have exchange-value in itself because it is in the equivalent form. Likewise, what makes a thing into money is its position in a certain social relation. However, this process of mediation vanishes and what appears 
to happen is that a particular commodity only has a value because it is expressed in the general equivalent form (money). ${ }^{4}$ It seems as if objects had a value inherent to their own structure as things, whereas they have value in so far as they are posited in the form of commodity. The fact that these forms of appearance are objectively necessary to this specific mode of production, makes that the categories that structure this objectivity appear as laws of nature or laws with natural necessity, therefore as categories trans-historically valid (MEW 23, p. 89; pp. 95-6).

By Kracauerian moment we mean a certain approach to Kant's first Critique transmitted from Siegfried Kracauer to Theodor Adorno (Bernstein, 2020). The method essentially consisted in reading Kant not as an epistemologist, but "as a kind of coded text from which the historical situation of spirit could be read" (ADORNO, 1992, pp. 58-9; GS 11, p. 388). In the first moment of the critique, Marx read the highest accomplishments of classical political economy as the necessary forms of appearance of certain social and historical practices raised to theory. The second moment consists therefore in the process of decoding the categories of political economy, by showing how these objective modes of appearance are necessary expressions of objective economic relations proper to this mode of production. In that sense, they are not only subjective phenomena, but rather the necessary subjective manifestation of objective relations. Therefore, as a necessary form of appearance, fetishism is not a subjective error, it is rather "objectively deduced from the social a priori [gesellschaftlichen Apriori], the exchange process" (ADORNO, 1973, p. 190; GS 6, p. 190).

Hence, categories of political economy such as labor, value, money and prices, which are abstractions belonging to a specific mode of production appear as natural and trans-historical categories. Furthermore, the fact that things are endowed with activate powers, produces the objective illusion that the objects establish relation among themselves. In the concluding sections of the third volume of Capital, Marx approaches again the problem of fetishism in order to criticize what he calls the Trinity Formula. The absurdness of such formula, claims Marx, is the lack of conceptual stringency [begriffslose] of the thesis that capital and land produce their own

4 Marx knew that classical economy had already overcome that "naive" fetishism of money but interrogated himself: "And modern economy, which looks down which such disdain on the monetary system, does not its superstition come out as clear as noon-day, whenever it treats of capital?" (MECW 35, p. 93; MEW 23, p. 97). 
revenues, interest and rent respectively. The irrationality of such formulation is the belief that things can by themselves produce more things. Marx takes pains to demonstrate that these two factors are actually shares of the total surplus-value produced by labor power (MEW 25, p. 829). Living labor is the category that allows Marx to ground all further categories of political economy on a concrete material basis. Hence, Enrique Dussel is right to claim that fetishizing involves the failure to recognize living labor as the material source of the categorial system (DUSSEL, 2001, p. 136).

The two moments of the critique of fetishism, the Kantian and the Kacauerian, are crucial to Marx's critique of political economy. First, they permit Marx to shift the theory of political economy to the problem of forms and to access the essence of real abstractions. The categories of political economy are abstract expressions of real economic relations and they constitute a certain transcendental frame that necessarily structures the form of life built upon a historically given mode of production. Second, they allow Marx to argue that this transcendental structure is necessary only to this given historical instance. Vulgar economists, according to Marx's definition, are the ones who simply take the forms of appearance as what is and thereby skirt past the scientific issue. They merely give voice to fetishism apologetically (MEW 25, pp. 825-6). In contrast, classical political economists, by searching for the essence of these forms of appearance, were able to grasp some important determinations of economic categories. Nevertheless, they were unable to clearly formulate the problem in terms of forms and thus failed to understand the historical determination of the categories (MEW 23, p. 95).

\section{Final remarks}

The fact that the terms "alienation" and "alienated" appear in mature texts such as the Grundrisse or Capital should not mislead us about the fate of this notion. It is true that the main intuitions of Marx's theory of alienation - i.e., the ontological inversion of subject and predicate through a critique of Hegel's speculative philosophy, and the notion that objects of human activity appear to them as alien objects endowed with active powers - remain unaltered through his entire intellectual trajectory. In that sense, we can see a clear connection between his theory of alienation and the mature 
critique of fetishism. The latter, in contrast, aims at bringing the categories of political economy, which appear as autonomous and trans-historically valid, back to the historically conditioned material relations of production and reproduction of life. By doing so he demonstrates that the abstract categories that organize social life and seem endowed with a life of its own are actually real abstractions of concrete and material social practices. In that connection, he can say that the economic forms appear as something alien [entfremdeten Erscheinungsform] (MEW 25, p. 825). Nevertheless, Marx does however completely abandon the naive anthropological understanding of alienation, based on the idea of human beings in relation to an idealized "generic man". This fact taken by itself undermines the consistency of anthropological accounts of alienation. A theory which, as Adorno claims, is "untenable" (ADORNO, 1973, p. 278; GS 6, p. 274). Not even to mention the embarrassment of imagining the meaning of a world in which nothing was alien (Ibid., p. 172). The critique of fetishism is freed from such embarrassments given that it operates as an immanent critique of the categorial system of political economy, showing how it detaches itself from its historical and material basis coming to appear as autonomous and trans-historical.

Through the critique of fetishism, the critique of political economy becomes a broader critique of a form of life based on the commodity-form and its further determinations. Such critique clarifies how the development of bourgeois society did not free humanity from illusions. On the contrary, it produced new and more deeply ingrained types of mystification, in the sense that they became more prosaic and profane. As Safatle argues, everything occurs as if the "disenchanted sphere of economic exchange were, at root, the space of construction and processes similar to those we find in the sphere of religious enchantment" (SAFATLE, 2010, p. 110).

Within this disenchanted sphere of economic exchange, subjects act as if they knew nothing, like perfect utilitarians, and value (or price) is seen as a natural feature of a given good. "We are not aware of this, nevertheless we do it" (MECW 35, p. 85; MEW 23, p. 88), wrote Marx, in his most celebrated phrase regarding the process of commodity exchange in capitalist society. This process depends necessarily on this not knowing, on an absence which constitutes the very essence of its social reality. As Žižek (2008) argues, commenting on Marx's phrase cited previously, the essence of ideology is in "doing" and not in "knowing". In other words, belief in 
capitalism is not required for the system's machinery to function; to the contrary, it is automatic, self-propelling, as Marx puts it, capital is an "automatic subject" [automatisches Subjekt]. Theoretically, human beings may be enlightened, as long as their concrete praxis remains enchanted - they become secular, but things come to believe on their behalf. This intuition is what would allow Walter Benjamin to assert that capitalism is a religion, but purely a cult, bereft of dogma. Hence the utilitarian doing is a belief in itself, translated into material practice. Guy Debord states: "Spectacular technology has not dispersed the religious mists into which human beings had projected their own alienated powers; it has merely brought those mists down to earth" (DEBORD, 2015, p. 12). This sentence abridges the Marxian critique of the mystic character of the commodity producers' society. The religious illusion is translated into a mundane basis, where human power is alienated from him.

It is important to highlight how the Marxian concept of fetishism can be applied to a range of models of critique, from ideological to aesthetic to epistemological. The force of a concept lies in its capacity to illuminate both old and new phenomena. Modern Western consciousness will never free itself from the shadow of fetishism.

\section{References}

ALAIN, Rey. Dictionnaire historique de la langue française. Paris: Le Robert, 2012.

ADORNO, T.W. Gesammelte Schriften [GS]: 20 Bände. Frankfurt am Main, 2003.

ADORNO, T.W. Negative Dialectics. Great Britain: Routledge \& Kegan Paul Ltd., 1973.

ADORNO, T.W. Notes to Literature: Volume Two. New York: Columbia University Press, 1992.

ADORNO, T.W.; HORKHEIMER, M. Dialectic of Enlightenment. Stanford University Press, 2002.

BASS, A. On the History of Fetishism: De Brosses and Comte. The Undecidable Unconscious: A Journal of Deconstruction and Psychoanalysis, 2, 2015, pp. 19-45

BENJAMIN, W. Capitalism as religion. In. MENDIETA, E. The Frankfurt School on Religion. New York and London: Routledge, 2005.

BERNSTEIN, J.M. “Concept and Object: Adorno's Crtique of Kant. In: GORDON, P. HAMMER, E.; PENSKY, M. (Editors). A Companion to Adorno. Hoboken: Wiley, 2020.

CHAMLEY, P. Économie Politique et Philosophie chez Steuart et Hegel. Paris: Librairie Dalloz, 1963 CHAMLEY, P. Les origines de la pensée économique de Hegel. Hegel-Studien 3, 1965, pp. 225-261. DEBORD, G. Society of the Spectacle. London: Rebel Press, 2015. 
DUSSEL, E. Towards an Unknown Marx: a commentary on the Manuscripts of 1861-3. New York: Routledge, 2001.

FEUERBACH, L. The Fiery Brook: Selected Writings. New York: Verso, 2012.

HEGEL, G.W.F. Elements of the philosophy of right. Cambridge: Cambridge University Press, 1991.

KOSIK, K. Dialética do concreto. Rio de Janeiro: Paz e Terra, 1972.

LIMA VAZ, H. Sobre as fontes filosóficas do pensamento de Karl Marx. In: CHASIN, J. (org). Marx Hoje: Cadernos Ensaio 1. São Paulo: Editora Ensaio, 1987.

MANDEL, E. Formation of Marx's economic thought. Rio de Janeiro: Zahar Editores, 1980.

MARCUSE, H. Sobre os fundamentos filosóficos do conceito de trabalho da ciência econômica. In: MARCUSE, H. Cultura e Sociedade. Rio de Janeiro: Paz e Terra, 1998.

MARX, K. Excertos do livro de James Mill "Éléments d'économie politique". Cadernos de Filosofia Alemã: Crítica e Modernidade, v. 21, n. 1, 2016, 147-161.

MARX, K.; ENGELS, F. Marx \& Engels Collected Works [MECW]: 50 Volumes. Digital Edition: Lawrence \& Wishart, 2010.

MARX, K.; ENGELS, F. Karl Marx und Friedrich Engels Gesamtausgabe [MEGA]. Berlin: Dietz Verlag, 1976.

MARX, K.; ENGELS, F. Karl Marx und Friedrich Engels Werke [MEW]: 43 Bände. Berlin: Dietz Verlag, 1962-1990

PAULA, J.A. de. O "Outubro" de Marx. Nova Economia, v. 18, n. 2, 2008, 167-190.

POSTONE, M. Time, labor, and social domination: a reinterpretation of Marx's critical theory. Cambridge: Cambridge University Press, 2003.

PRIDDAT, B. Hegel als Ökonom. Berlin: Duncker \& Humblot 1990.

REICHELT, H. Sobre a estrutura lógica do conceito de capital em Karl Marx. Campinas: Editora da Unicamp, 2013.

RUBIN, I. Essays on Marx's theory of value. Black Rose Books, 1990.

RUDA, F. Hegel's rabble. Continuum, 2011.

SAFATLE, V. P. Fetichismo: colonizar o Outro. Rio de Janeiro: Civilização Brasileira, 2010.

WASZEK, N. The Scottish enlightenment and Hegel's account of 'civil society'. Kluwer Academic Publishers, 1988.

ZELENÝ, J. La estructura lógica de "El Capital" de Marx. Barcelona: Ediciones Grijalbo, 1974.

ZIZEK, S. The sublime object of ideology. London: Verso, 2008.

\section{About the authors}

Tomás Lima Pimenta - pimet023@newschool.edu

New School for Social Research, New York, United States.

ORCID: https://orcid.org/0000-0003-4614-8847.

\section{About the article}

Submission received on August 10, 2018. Approved for publication on March 13, 2019. 